\title{
Exploring the Sustainable Shareholder Value of Corporate Social Responsibility Activities
}

\author{
Dr. Dra. Juniarti,
}

\section{Petra Christian University, Indonesia}

\begin{abstract}
:
This research aims to explore the long-term benefit of the consistent implementation of CSR activities in creating sustainable value for shareholders, based on the argumentation of a sustainability approach. The measurement of sustainable shareholder value uses an accounting-based and market-based approach. Since the benefit of CSR cannot be expected in the short-term but in the longer-term, this study requires that the companies should have implemented CSR for at least five years to be included in this research sample. These results support the argumentation of sustainability in which CSR has a positive association with the sustainable shareholder value using both accounting-based and market-based measurement. In addition, this research also uncovers that there is a difference association model of CSR and sustainable shareholder value between firms that have high social and environmental risk (high-profile companies) and firms that have low social and environmental risk (low-profile companies).
\end{abstract}

Keywords: Corporate Social Responsibility, Sustainability, Indonesia, Sustainable Shareholder Value 


\section{Introduction}

In the past three decades, studies and concerns on Corporate Social Responsibility (CSR) have grown noticeably. Despite the increasing attention from various parties, it is still contested whether corporations should take social responsibility beyond wealth generating functions and serving shareholder interest. According to Shareholder Value Theory, the primary function of the company is to maximize shareholder value (Friedman, 1970; Griffin and Mahon, 1997). Proponents of Shareholder Value Theory (e.g. Bansal, 2005; Griffin and Mahon, 1997; Carroll and Shabana, 2010; Slater, 2000) argue that corporate social responsibility will diminish shareholder value since CSR activities not only increase cost but also provide benefit to the shareholders. The emphasis on the shareholders' interest has drawn widespread criticism, especially after a series of financial scandals in the 2000s (e.g. Enron, Worldcom, Lehman Brothers, and Bernard Madoff). Stakeholder Theory, on the other hand, suggests that the purpose of a business is to create value for different stakeholders, including customers, suppliers, employees, communities and shareholders (Donaldson and Preston, 1995; Pirsch et al., 2007; Whelan and Pink, 2016). Companies that keep the interests of the stakeholders aligned are more likely to create value and be sustainable over time (Pirsch et al., 2007; Roberts, 1992; Steurer et al., 2005).

This research proposes a sustainability approach to mediate the arguments between shareholder value theory and stakeholder theory, concerning whether corporations have social responsibility on their stakeholders. From a sustainability perspective, CSR share normative goals with the concept of sustainable practices such as improving environmental and social impacts. As Porter and Kramer (2011) argue, companies could create economic value while addressing social problems that intersect with their business interests. While existing research studied the relationship between CSR and short-term performance, only a few studies associated it with shareholder value, namely, Becchetti et al. (2012), Hillman and Keim (2001), Godfrey et al. (2009) and Sanchez and Sotorio (2007).

The remainder of the paper will discuss the literature review which contains explanations of theory, empirical studies and hypotheses, and the research methods which are included in the approach used in the study and the data analysis. These findings show the results of hypothesis testing, with a discussion on the interpretation of the results of the research. The last part is conclusions, implications, and research opportunities.

\section{Literature Review}

\subsection{CSR in Indonesia}

In 2007, Indonesia issued the Corporate Act No. 40, which imposes a mandatory corporate social and environmental responsibility regime on limited liability companies that involve the management and exploitation of natural resources. Sanctions can be imposed for failure to comply with allocating and spending obligatory funding to implement CSR. To a certain extent, the mandatory nature of new regulation gives rises to controversy since it calls for a need to redefine the

International Journal of Management and Applied Research, 2018, Vol. 5, No. 2 
concept of corporate social responsibility. Over the years, the Indonesian government has introduced a number of initiatives and regulatory changes to promote socially responsible behaviours such as reforestation (Rosser and Edwin, 2010) and countering corruption, and yet the weak law enforcement mechanisms could undermine the implementation of CSR activities (Waagstein, 2011).

\subsection{Earning Persistence}

The first hypothesis we test is whether CSR boost shareholder value over time. The rationale is that financial markets should be increasingly sensitive to CSR activities due to the following reasons: first, interest of investors grows over time (Becchetti et al. (2012); second, CSR practice has spillover effects on market returns (Bobbie, 2017), and lastly, CSR strategies have long-term effects on shareholder value (Hart and Milstein, 2003; Roberts and Dowling, 2002; Whelan and Fink, 2016). Investors begin to value sustainable practices due to its effect on financial performances (Whelan and Fink, 2016). For instance, Asumadu-Sarkodie and Owusu (2016) show that solar photovoltaic investment has an average internal rate of return of $2.3 \%$ to $24.2 \%$. Furthermore, better management of natural resources not only reduces environmental impacts but also improve operational efficiency as well as minimise waste. In other words, CSR activities can help to address environmental and social problems that help to contribute to a more sustainable world and at the same time, increase and sustain shareholder value.

The concept of sustainable shareholder value can be traced back to the work of Hart and Milstein (2003) who used the term "sustainable value" to describe shareholder value. They developed a four-component model of sustainable shareholder value involving current needs, future growth, internal skills, and external knowledge. Each of these four components represents a strategic move in relation to sustainability and wealth creation. For example, if a firm focuses on the current and internal organisational skills, it is likely that the firm would adopt cost and risk reduction CSR strategy, such as waste reduction and pollution prevention; conversely, if a firm focuses on future growth and internal organisational skills, it is likely that the firm would aim to improve its competencies and adopt new technologies. Hart and Milstein (2003) argue that the ability to create sustainable value requires strong performance in four areas.

Henisz et al. (2014) suggests that implementing CSR activities can be conceived as investments in political and social capital which ultimately generate sustainable shareholder value. Such argument is consistent with prior studies where the relationship between CSR and shareholder value is found to be positive (e.g. Becchetti et al., 2012; Godfrey et al., 2009; Hillman and Keim, 2001; Sánchez and Sotorrío, 2007). In a study of corporate reputation, Roberts and Dowling (2002) found that reputable firms, especially those who engage in CSR activities, are better at sustaining profits over time. Arguably, however, the relationship between CSR and shareholder value differs across the industries and nations. Sun et al. (2018) found that initial CSR engagement increase shareholder value, and yet shareholder value turns negative when a firm pursues excessive CSR activities, especially if the firm has low marketing capability.

International Journal of Management and Applied Research, 2018, Vol. 5, No. 2 
On the basis of the above observations, the author propose:

H1: CSR Index (CRSI) has a positive association with earning persistence

\subsection{Cumulative Abnormal Return (CAR)}

The second hypothesis we want to test is whether CSR reporting is associated to significant abnormal returns. To examine the stock price reaction to the announcement of CSR reports, Cumulative Abnormal Return (CAR) is used in this research. Cumulative abnormal return (CAR) is the sum of abnormal returns during a specified window, which is suitable for testing our second hypothesis.

The impacts of announcements of corporate illegalities or CSR activities on shareholder returns are well-documented (e.g. Dijken, 2007; Fombrun, 1997; Golebiewska, 2014; Patten, 2008). In assessing the effect of CSR announcement on companies' stock performance, Bobbie (2017) found that there were significant negative and positive responses to the CSR announcements in the market; more specifically, good news generated a cumulative abnormal return of $0.61 \%$, whereas bad news caused the stocks to drop by $-0.57 \%$. Similarly, Hendarto and Purwanto (2012) found that Indonesian listed companies have been implemented CSR, long before CSR became mandatory, enjoyed positive abnormal returns immediately after the government made it compulsory. Other studies that support the association of CSR related press release and shareholder value include: Godfrey et al. (2009); Hillman and Keim (2001) and Sánchez and Sotorrío (2007).

On the basis of the above, the author propose:

H2: CSR Index (CRSI) has a positive association with the cumulative abnormal return.

\section{Research Method}

\subsection{Data Collection}

Using panel data on 214 public companies listed on the Indonesian Stock Exchange (IDX) over the period 2007-2012, this study aims to examine the introduction of mandatory CSR on Indonesia companies. Since the adoption of the 2007 Indonesian Law No. 40 involves companies conducting their business activities in the field of natural resources, the data sampling excludes the finance sector. This study acknowledges that selecting a purposive data sample implies that any inferences drawn from the study, are confined to the actual companies studied, and cannot therefore be extrapolated across the entire population.

\subsection{Data Analysis}

In this study, sustainable shareholder value is proxied by the persistence of earnings and cumulative abnormal return (CAR). Each represents accounting-based and marketbased measurement. There are two proposed models to test the hypothesis. Each model will be tested simultaneously with six control variables: industry profiles, earnings, leverage, firm size, book to market equity, competition intensity. Research models of this study are as follow:

International Journal of Management and Applied Research, 2018, Vol. 5, No. 2 
PERSIST $_{i, t}=\beta_{0}+\beta_{1}$ CSRI $_{i, t-1}+\beta_{2}$ PROFIL $_{i, t-1}+\beta_{3}$ PROFIL $_{i, t-1} * \operatorname{CSRI}_{i, t-1}+\beta_{4} L E V_{i, t-1}+$

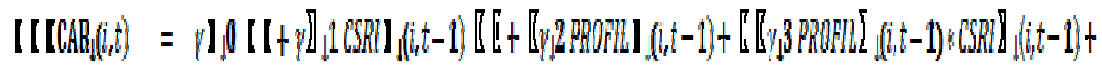

\author{
$\beta_{5} U P_{i, t-1}+\beta_{6} B M E_{i, t-1}$

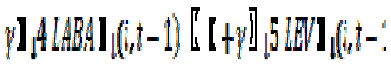

where:

$\mathbf{C A R}_{i, t}=$ Cumulative abnormal returnfor firm $i$, year $t$

PERSIST $_{i, t}=$ persistent earnings for firm $i$, year $t$

$\operatorname{CSFI}_{i,-1}=\mathrm{CSR}$ index for firm $i$, year $t-1$

$L A B A_{i, t-1}=$ earnings for firm $i$, year $t-1$

$L E V_{i, t-1} \quad=$ leverage for firm $i$, year $t-1$

$U P_{i, t-1} \quad=$ firm size for firmi, year $t-1$

$B M E_{i, t-1}=$ book to market equityfor firmi, year $t-1$

PROFIL $_{i, t-1}=$ industry profile for firm $i$, year $t-1$

$I_{P E R_{i, t-1}}=$ competition intensity for firmi, year $t-1$

$\beta_{0}, \gamma_{0} \quad=$ intercept

$\beta_{1}-\beta_{7} \quad=$ slope of model 1

$\gamma_{1}-\gamma_{\mathbf{s}} \quad=$ slope of model 2

$\varepsilon_{i, t} \quad=$ error

\title{
Variables
}

Corporate Social Responsibility

This research uses GRI Guideline to measure CSR implementation. GRI is one of the reputable guidelines and has been widely adopted in many countries (Fuente et al., 2017; Global Reporting Initiative, 2015; Toppinen and Korhonen-Kurki, 2013; Wagner and Seele, 2017). The level of CSR implementation is measured by comparing CSR activities reported by companies with the guideline. If companies report their activities under the GRI guideline they are score done, otherwisethey are scored zero. Then all scores are added and scaled by total scores in GRI to obtain CSR score for each company.

\section{Sustainable Shareholder Value}

Sustainable shareholder value is proxied by persistent earnings and cumulative abnormal earnings (CAR).

Persistent Earnings

Based on the study of Francis et al. (2004), this study adopts first-order autocorrelation model (AR1) to value persistent earnings. The AR1 model requires several prior periods of earning, usually more than five years to obtain the coefficient of persistent earnings. The slope coefficient is obtained from the following AR1 model:

$\mathbf{x}_{j, t}=\varphi_{0, \mathrm{j}}+\varphi_{1_{i}} X_{j, t-1}+\mu_{j, r}$

(3)

Where:

$\mathrm{X}_{\mathrm{j}, \mathrm{t}}=$ firm earnings year $\mathrm{t}$

$X_{j, t-1}=$ firm earnings year $t-1$

International Journal of Management and Applied Research, 2018, Vol. 5, No. 2 
Earning is the net income before extraordinary items divided by the weighted average number of outstanding shares. For each observation, use at least seven years window. Value of $\varnothing_{1, \mathrm{j}}$ close 1 implies highly persistent earning, the value of $\varnothing_{1, \mathrm{j}}$ close 0 suggest lower persistent earning (Belkaoui, 2004; Bredal and Negård, 2015; Francis et al., 2004).

Cumulative Abnormal Return (CAR)

CAR is measured using a market model (Aguinis and Glavas, 2012; Godfrey et al., 2009; Bird et al., 2007), with the following steps:

1. Choose the event window; this research uses a 12 months event window ($3,0,+8)$, three months before the month of financial reporting issued, and eight months after the month of the publication month. Month 0 is the month of the annual report publication

2. Regress monthly stock return to the market return for 60 months to obtain estimation parameters $(\alpha, \beta)$, with the following formula:

(4)

$$
R_{i t}=\alpha+\beta_{i} R_{m t}+\varepsilon_{i t}
$$

3. Calculate expected return $E\left(R_{i t}\right)$ using $\alpha$ and $\beta$ from above step, with the following formula:

I $\quad \mathrm{E}\left(R_{\lambda_{i t}}\right)=\alpha+\beta_{i} R_{m i t}$

(5)

4. Calculate abnormal return (AR) share $\mathrm{i}$ for month $\mathrm{t}$, with the following formula:

$$
A R_{i t}=R_{i t}-\llbracket \mathrm{E}\left(R \rrbracket_{i t}\right)
$$

5. Calculate CAR by adding 12 months event window of $\mathrm{AR}$, as follow:

$$
\mathrm{CAR}_{i}=\sum_{t=3}^{t+8} A R_{i t}
$$

Current Earning ( $L A B A)$ is measured by net income before extraordinary item divided by average total assets (Holbrook, 2010; Dhaliwal et al., 2011).

Leverage $(L E V)$ is measured by total debt divided by total assets.

To control Firm Size (UP), the author measured a firm's total market capitalization (Log Market Value) at the end of accounting period (Belkaoui, 2004; Bird et al., 2007; Holbrook, 2010).

Book to Market Equity (BME) is measured by the book value of equity divided by the market value of equity.

Competition intensity (IPER) is measured using Herfindahl index (HHI), calculation of $\mathrm{HHI}$ is obtained from the following formula:

$H H I_{i t}=S_{1}{ }^{2}+S_{2}{ }^{2}+S_{3}{ }^{2}+\cdots+S_{n}{ }^{21}$

International Journal of Management and Applied Research, 2018, Vol. 5, No. 2 
where:

$S_{1}, S_{2} \ldots S_{n}=$ market share of firms in the same industry

\section{Industry Profile (PROFIL)}

Prior studies have categorised industries into high-profile and low-profile according to industry characteristics (e.g., sales growth, market share of the firm, regulatory risk, and the intensity of competition), and these studies have demonstrated a positive association between such an industry classification and CSR disclosure (Lu and Abeysekera, 2014; Roberts, 1992). Lu and Abeysekera (2014), for instance, showed that high-profile industries (e.g. high consumer visibility and high polluting industries) are more likely to make more social and environmental disclosure than the low-profile industries. In this study, we classified industry profiles into two groups: the highprofile industry $(\mathrm{H})$ and low-profile industry $(\mathrm{L})$ based on the operational activities of the firms. Industry profile is measured using dummy variables corresponding to the industrial group, 1 for a high-profile industry and 0 for the low-profile sector.

\section{Results and Discussion}

\subsection{Sample Profiles}

Based on the sample's criteria, 214 firm-years qualify with the requirements during two years of observation. Data are analyzed using Eviews 8. Table 1 shows the descriptive statistics of the observation.

Table 1: Statistic Descriptive

\begin{tabular}{lrrrrr}
\hline Variable & \multicolumn{1}{c}{ Mean } & \multicolumn{1}{c}{ Median } & Maximum & Minimum & Std. Dev \\
\hline CAR & -0.14699 & -0.16817 & 1.39064 & -1.16952 & 0.44316 \\
PERSIST & 0.44013 & 0.52550 & 0.99200 & -0.92000 & 0.42238 \\
CSRI & 0.22636 & 0.23810 & 0.57143 & 0.05952 & 0.10586 \\
LEV & 0.57860 & 0.46733 & 8.24998 & 0.07071 & 0.71579 \\
UP & 6.09557 & 6.03310 & 8.41262 & 4.22272 & 0.88558 \\
BME & 0.80034 & 0.80298 & 7.35293 & -18.83421 & 1.77962 \\
IPER & 0.30090 & 0.23706 & 0.90894 & 0.07411 & 0.18842 \\
LABA & 134.62190 & 6.60619 & 2268.99400 & -94.78699 & 330.87610 \\
PROFIL & & \multicolumn{5}{c}{ HIGH } & 97 & $45,33 \%$ \\
& & \multicolumn{5}{c}{ LOW } & 117 & $54,67 \%$ \\
\hline
\end{tabular}

Overall, samples have moderate CSRI scores. The average score of CSRI is $22.64 \%$, which means that companies have an adequate concern to implement CSR. Based on the value of standard deviation we can conclude that variance of the implementation among companies is quite low. CSR implementations are expected to be greater in a high-profile industry group in comparison to low-profile group due to the higher risk of pollution and thus subject to tighter regulatory controls (Lu and Abeysekera, 2014). From the results of a T-Test (Table 2), the average CSRI in both sample groups is significantly different at the 0.01 significance level. Based on firm size, the results show that CSRI at large and small companies are significantly different at a

International Journal of Management and Applied Research, 2018, Vol. 5, No. 2 
significance level of 0.1. However, there is no difference of CSRI in high and low intensity of competition. This is likely due to the majority of the samples being in high intensity of competition.

Table 2: Independent Sample T-Test

\begin{tabular}{llrrr}
\hline Sample Group & & N & Mean & Std. Dev \\
\hline Industry Profile & High profile & 97 & 0.22201 & 0.11930 \\
& Low profile & 117 & 0.23036 & 0.09257 \\
Firm Size & Big & 110 & 0.21806 & 0.10769 \\
& Small & 104 & 0.23557 & 0.10257 \\
Competition Intensity & High & 186 & 0.22465 & 0.10643 \\
& Low & 28 & 0.23936 & 0.09872 \\
\hline \multirow{2}{*}{$, * *, * * *=$ significant at level $0.1,0.05$ and 0.01 respectively }
\end{tabular}

\subsection{Test of Hypothesis 1}

Hypothesis 1 tested the association between CSR and sustainable shareholder value proxied by earnings persistence (PERSIST). The association model of CSR and persistence of earnings is presented in Table 3. The model shows that the persistence of earnings will increase by $0.5447 *$ CSRI, the higher CSR index, the higher the earnings persistence of the companies. The results show that there was no difference of association model between high profile and low profile companies. Even though theoretically high profile companies have amore significant impact on society and the environment, and would be subject to the rules of higher costs for pollution control and other expenses related to the environmental effects (Konar and Cohen, 2001), but the empirical results show differently. Overall, the equation model meets the goodness of fit indicated with the value of adjusted R2 amounted to $14.88 \%$ and the value of $\mathrm{F}$ significant at the 0.01 .

Table 3: Results of Hypothesis 1 Test

\begin{tabular}{|c|c|c|c|c|c|c|}
\hline \multirow{2}{*}{ Description } & \multicolumn{3}{|c|}{ Model 1a } & \multicolumn{3}{|c|}{ Model 1b } \\
\hline & Coefficient & t-stat & $\mathrm{Sig}$ & Coefficient & t-stat & Sig \\
\hline CSRI & 0.77626 & 2.88798 & $* * *$ & 0.54472 & 1.99451 & ** \\
\hline PROFIL & & & & -0.03133 & -0.48348 & \\
\hline PROFIL* CSRI & & & & -0.04018 & -0.45598 & \\
\hline LEV & & & & -0.02225 & -0.49170 & \\
\hline UP & & & & 0.04257 & 1.18889 & \\
\hline BME & & & & -0.03179 & -1.89941 & * \\
\hline IPER & & & & 0.14191 & 0.94905 & \\
\hline $\mathrm{C}$ & 0.26442 & 3.93833 & $* * *$ & 0.12064 & 0.38713 & \\
\hline R-squared & 0.03785 & & & 0.19296 & & \\
\hline Adj R-squared & 0.03331 & & & 0.14879 & & \\
\hline F-stat & & 8.34045 & $* * *$ & & 4.36893 & $* * *$ \\
\hline
\end{tabular}

\subsection{Test of Hypothesis 2}

Hypothesis 2 tests the association between CSR and sustainable shareholder value proxied by the CAR. The testing of model $2 \mathrm{~A}$ without entering a control variable

International Journal of Management and Applied Research, 2018, Vol. 5, No. 2 
shows the positive association of CSRI and CAR, but this is not significant. Further testing of CSR includes all the control variables (model 2B) shows that model fulfills the goodness of fit and has higher $\mathrm{F}$ than prior tests (model 2A). The results show that PROFILE in models $2 \mathrm{~B}$ is significant at 0.05 level whereas the CSR PROFILE * is significant at the 0.01 significance level. PROFILE provides a substantial difference in the model association of CSR and CAR. A high slope on association model of CSR and CAR of 0.57531 indicates that the implementation of CSR in the high-profile group of companies provides a sharp rise in the CAR. Contrarily, if the company ignores the implementation of CSR or fails to fulfill these responsibilities, it will be followed by a significant decrease in CAR as well. A high-profile group always receives a higher CAR, compared with a low profile. The market will still appreciate the social responsibility actions undertaken by the high profile group.

Table 4. Results of Hypothesis 2 Test

\begin{tabular}{|c|c|c|c|c|c|c|}
\hline \multirow[t]{2}{*}{ Description } & \multicolumn{3}{|c|}{ Model 1a } & \multicolumn{3}{|c|}{ Model 1b } \\
\hline & Coefficient & t-stat & Sig & Coefficient & t-stat & Sig \\
\hline CSRI & -0.41852 & -1.24337 & & -0.41572 & -1.44082 & \\
\hline PROFIL & & & & 0.10926 & 1.82119 & * \\
\hline PROFIL* CSRI & & & & 1.01182 & 10.83324 & $* * *$ \\
\hline LEV & & & & 0.06337 & 1.47316 & \\
\hline UP & & & & -0.00291 & -0.07385 & \\
\hline BME & & & & 0.01698 & 0.96830 & \\
\hline IPER & & & & 0.06498 & 0.40940 & \\
\hline LABA & & & & 0.00004 & 0.41726 & \\
\hline $\mathrm{C}$ & -0.01442 & -0.71169 & & -0.07336 & -0.29421 & \\
\hline R-squared & 0.00727 & & & 0.38260 & & \\
\hline Adj R-squared & 0.00257 & & & 0.35839 & & \\
\hline F-stat & & -1.61043 & & & 15.80253 & $* * *$ \\
\hline
\end{tabular}

\section{Discussion}

Results show that the CSR activities have a positive and significant association with sustainable shareholder value proxied by the persistence of earnings. The results also reinforce the view that engagement in sustainable practices and CSR activities generate long-term shareholder value (Achda, 2006). Our main findings document that the impact of CSR activities has risen over time, and that the abnormal returns around the announcement of CSR reporting are positive. The results of this study complements previous research conducted by Hendarto and Purwanto (2012) in Indonesia, Cheung et al., (2010) on Asian firms; Hillman and Keim (2001) on S\&P firms; Sánchez and Sotorrío (2007) in Spain.

However, the association model of CSR and CAR varies across industries. In highprofile industries, the consistent implementation of CSR is valued by the market. A high-profile company is a company whose operations are more related to the utilization of natural resources. These industry groups are committed to implement CSR and deliver sustainable value to shareholders. On the other hand, CSR activities seem to have fewer impacts on stock performance in the low-profile industry group.

International Journal of Management and Applied Research, 2018, Vol. 5, No. 2 


\section{Conclusion}

This research address the concerns related to the benefits that can be provided to shareholders by companies that consistently implement CSR. It is proven that the company's involvement in CSR activities generates sustainable shareholder value. These results also reinforce the confidence of the proponents of a sustainability approach. That is, companies which take responsibility for social and environmental concerns will earn higher profits in the long term. The concerns of the proponents of shareholder value theory that the implementation of CSR impedes the company capability to deliver value to shareholders are not proven.

Our study provides several managerial implications, particularly for Indonesian firms as well as multinational enterprises that currently have, or seek to establish, subsidiary operations in Indonesia. First, CSR strategy should be aligned with both current needs and future growth of the company. Rather than engaging CSR activities that are remotely connected to business interests, organisations should be more careful with resource allocation and low carbon investment. International managers should also be careful not to assume that financial return on CSR activities is immediate.

\subsection{Limitation and Future Research}

The limitations of this research are as follows. First, this research only focused on shareholder value and assumed that all other stakeholders including employees, customers, suppliers, and the local community have benefited from the CSR activities. While this research proves that the companies are able to deliver shareholders value, future research could consider creating shared values with all key stakeholders. Second, in this research, the evaluation of CSR implementation is only based on the disclosure of CFR in the annual report due to access constraint. Future research could explore the value of CSR from various stakeholders to support the argumentation of stakeholders theory that the ability of companies to accommodate all stakeholders' interests. Other possible source to evaluate the CSR implementation, such as comparison with external assurance, is highly recommended for future research.

\section{References}

1. Achda, B. T. (2006), "The Sociological Context of Corporate Social Responsibility Development and Implementation in Indonesia", Corporate Social Responsibility and Environmental Management, Vol. 13, No. 5, pp. 300-305. https://doi.org/10.1002/csr.133

2. Aguinis, H. and Glavas, A. (2012), "What We Know and Don't Know About Corporate Social Responsibility: A Review and Research Agenda", Journal of Management, Vol. 38, No. 4, pp. 932 - 968. https://doi.org/10.1177/0149206311436079

3. Asumadu-Sarkodie, S. and Owusu, P. A. (2016), "The potential and economic viability of solar photovoltaic power in Ghana", Energy Sources, Part A: Recovery, Utilization, and Environmental Effects, Vol. 38, No. 5, pp. 709-716, https://doi.org/10.1080/15567036.2015.1122682

International Journal of Management and Applied Research, 2018, Vol. 5, No. 2 
4. Bansal, P. (2005), "Evolving Sustainably: A Longitudinal Study of Corporate Sustainable Development", Strategic Management Journal, Vol. 26, No. 3, pp. 197-218. https://doi.org/10.1002/smj.441

5. Becchetti, L., Ciciretti, R., Hasan, I. and Kobeissi, N. (2012), "Corporate social responsibility and shareholder's value", Journal of Business Research, Vol. 65, No. 11, pp. 1626-1635. https://doi.org/10.1016/j.jbusres.2011.10.022

6. Belkaoui, A. R. (2004), "The Impact of Corporate Social Responsibility on the Informativeness of Earnings and Accounting Choices", in: (Ed) Advances in Environmental Accounting and Management, Volume 2, Emerald Group Publishing Limited, pp. 121 - 136.

7. Bird, R., Hall, A. D., Momente, F., and Reggiani, F. (2007), "What corporate social responsibility activities are valued by the market?", Journal of Business Ethics, Vol. 76, No. 2, pp. 189-206. https://doi.org/10.1007/s10551-006-9268-1

8. Bredal M. H. and Negård, N. (2015), The Price of Ethical Investing: Evaluating the performance of socially responsible indices, Master Thesis, Bergen: Norwegian School of Economics, [Online], available from: https://brage.bibsys.no/xmlui/bitstream/handle/11250/300219/MasterThesis.PDF?s equence $=1$ [accessed on 2 June 2018].

9. Bobbie, D. (2017), "Stock market response to CSR announcements: an event study of the Finnish pulp and paper industry", Master Thesis, Finland: Lappeenranta University of Technology, [Online], available from: http://urn.fi/URN:NBN:fi-



10. Carroll, A. and Shabana, K. M. (2010), "The Business Case for Corporate Social Responsibility: A Review of Concepts, Research and Practice", International Journal of Management Reviews, Vol. 12, No. 1, pp. 85-105. https://doi.org/10.1111/j.1468-2370.2009.00275.x

11. Cheung, Y. L., Tan, W., and Zhang, Z. (2010), "Does Corporate Social Responsibility Matter in Asian Emerging Markets?", Journal of Business Ethics, Vol. 92, No. 3, pp. 401-413. https://doi.org/10.1007/s10551-009-0164-3

12. Dhaliwal, D. S., Li, O. Z., Tsang, A., and Yang, Y. G. (2011), "Voluntary Nonfinancial Disclosure and the Cost of Capital: The Initiation of Corporate Social Responsibility Accounting", The Accounting Review, Vol. 86, No. 1, pp. 59-100. https://doi.org/10.2308/accr.00000005

13. Donaldson, T., and Preston, L. E. (1995), "The Stakeholders Theory of the Corporation: Concepts, Evidence, and Implications", The Academy of Management Review, Vol. 20, No. 1, pp. 65-91. https://doi.org/10.5465/amr.1995.9503271992

14. Francis, J., LaFond, R., Olsson, P. M., and Schipper, K. (2004), "Costs of Equity and Earnings Attributes", The Accounting Review, Vol. 79, No. 4, pp. 967-1010. https://doi.org/10.2308/accr.2004.79.4.967

15. Friedman, M. (1970), "The Social Responsibility of Business is to Increase its Profits", The New York Times Magazine, p. 12. [Online], Available from: https://www.nytimes.com/1970/09/13/archives/article-15-no-title.html [accessed on 1 June 2018].

International Journal of Management and Applied Research, 2018, Vol. 5, No. 2 
16. Fuente, J.A. García-Sánchez, I.M. Lozano, M.B. (2017), "The role of the board of directors in the adoption of GRI guidelines for the disclosure of CSR information", Journal of Cleaner Production, Vol. 141, pp. 737-750. https://doi.org/10.1016/j.jclepro.2016.09.155.

17. Global Reporting Initiative (2015), G4 Sustainability Reporting Guidelines [Online], Available from:

https://www.globalreporting.org/resourcelibrary/GRIG4-Part1-ReportingPrinciples-and-Standard-Disclosures.pdf [accessed on 1 June 2018].

18. Godfrey, P. C., Merrill, C. B., and Hansen, J. M. (2009), "The Relationship Between Corporate Social Responsibility and Shareholders value; An Empirical Test of The Risk Management Hypothesis", Strategic Management Journal, Vol. 30, No. 4, pp. 425-445. https://doi.org/10.1002/smj.750

19. Griffin, J. J., and Mahon, J. F. (1997), “The Corporate Social Performance and Corporate Financial Performance Debate-Twenty Five Years of Incomparable Research", Business and Society, Vol. 36, No. 1, pp. 5-31. https://doi.org/10.1177\%2F000765039703600102

20. Hart, S. L., and Milstein, M. B. (2003), "Creating Sustainable Value and Executive Commentary", Academy of Management, Vol. 17, No. 2, pp. 56-69. https://doi.org/10.5465/ame.2003.10025194

21. Henisz, W. J., Dorobantu, S. and Nartey, L. J. (2014), "Spinning gold: The financial returns to stakeholder engagement", Strategic Management Journal, Vol. 35, No. 12, pp. 1727-1748. https://doi.org/10.1002/smj.2180

22. Hendarto, K. A., and Purwanto, B. M. (2012), "Market Reactions of Mandatory Implementation of Corporate Social Responsibility: Indonesia Context", Asia Pacific Management Review, Vol. 17, No. 4, pp. 379-402. https://doi.org/10.6126/APMR.2012.17.4.03

23. Hillman, A. J., and Keim, G. D. (2001), "Shareholders Value, Stakeholders Management, and Social Issues: What's the Bottom Line?", Strategic Management Journal, Vol. 22, No. 2, pp. 125-139. https://doi.org/10.1002/10970266(200101)22:2<125::AID-SMJ150>3.0.CO;2-H

24. Holbrook, M. E. (2010), Corporate Social Responsibility and Financial Performance: An Examination of Economic Benefits and Costs as a Manifested in Accounting Earnings. Ph.D. Thesis, USA: University of Kentucky.

25. Konar, S., and Cohen, M. A. (2001), "Does the Market Value Environmental Performance?", The Review of Economics and Statistics, Vol. 83, No. 2, pp. 281289. https://www.jstor.org/stable/3211606

26. Lu, Y. and Abeysekera, I. (2014), "Stakeholders' power, corporate characteristics, and social and environmental disclosure: evidence from China", Journal of Cleaner Production, Vol. 64, pp. 426-436, https://doi.org/10.1016/j.jclepro.2013.10.005

27. Patten, D. M. (2008), "Does the market value corporate philanthropy? Evidence for the response to the 2004 Tsunami Relief Effort", Journal of Business Ethics, Vol. 81, No. 3, pp. 699-607. https://doi.org/10.1007/s10551-007-9534-X

International Journal of Management and Applied Research, 2018, Vol. 5, No. 2 
28. Pirsch, J., Gupta, S., and Grau, S. L. (2007), “A Framework for Understanding Corporate Social Responsibility Programs as a Continuum: An Exploratory Study", Journal of Business Ethics, Vol. 70, No. 2, pp. 125-140. https://doi.org/10.1007/s10551-006-9100-y

29. Porter, M. and Kramer, M. (2011), "Creating shared value", Harvard Business Review, Vol. 89, No. 1/2, pp. 62-77.

30. Roberts, R.W. (1992), "Determinants of corporate social responsibility disclosure: an application of stakeholder theory", Accounting, Organisations and Society, Vol. 17, No. 6, pp. 595-612. https://doi.org/10.1016/0361-3682(92)90015-K

31. Roberts, P. W., and Dowling, G. R. (2002), "Corporate Reputation and Sustained Superior Financial Performance", Strategic Management Journal, Vol. 23, No. 12, pp. 1077-1093. https://doi.org/10.1002/smj.274

32. Rosser, A. and Edwin, D. (2010), "The politics of corporate social responsibility in Indonesia", Pacific Review, Vol. 23, No. 1, pp. 1-22. doi:10.1080/09512740903398314

33. Sánchez, J. F., and Sotorrío, L. L. (2007), "The Creation of Value through Corporate Reputation", Journal of Business Ethics, Vol. 76, No. 3, pp. 335-346. https://doi.org/10.1007/s10551-006-9285-0

34. Slater, R. (2000), The GE way fieldbook, New York: McGraw-Hill Professional.

35. Steurer, R., Langer, M. E., Konrad, A., and Martinuzzi, A. (2005), "Corporations, Stakeholders and Sustainable Development I: A Theoretical Exploration of Business Society Relation", Journal of Business Ethics, Vol. 61, No. 3, pp. 263281. https://doi.org/10.1007/s10551-005-7054-0

36. Sun, W.; Yao, S. and Govind, R. (2018), "Reexamining Corporate Social Responsibility and Shareholder Value: The Inverted-U-Shaped Relationship and the Moderation of Marketing Capability", Journal of Business Ethics, pp. 1-17. https://doi.org/10.1007/s10551-018-3854-X

37. Toppinen, A. and Korhonen-Kurki, K. (2013), "Global Reporting Initiative and social impact in managing corporate responsibility: a case study of three multinationals in the forest industry", Business Ethics: A European Review, Vol. 22, No. 2, pp. 202-217. https://doi.org/10.1111/beer.12016

38. Waagstein, P. R. (2011), "The Mandatory Corporate Social Responsibility in Indonesia: Problems and Implications", Journal of Business Ethics, Vol. 98, No. 3, pp. 455-466. https://doi.org/10.1007/s10551-010-0587-X

39. Wagner, R. and Seele, P. (2017), "Uncommitted Deliberation? Discussing Regulatory Gaps by Comparing GRI 3.1 to GRI 4.0 in a Political CSR Perspective", Journal of Business Ethics, Vol. 146, No. 2, pp. 333-351. https://doi.org/10.1007/s10551-017-3654-8

40. Whelan, T., and Fink, C. (2016), "The Comprehensive Business Case for Sustainability". Harvard Business Review Digital Articles, pp. 2-8. [Online], Available from: https://hbr.org/2016/10/the-comprehensive-business-case-forsustainability [accessed on 1 June 2018].

International Journal of Management and Applied Research, 2018, Vol. 5, No. 2 